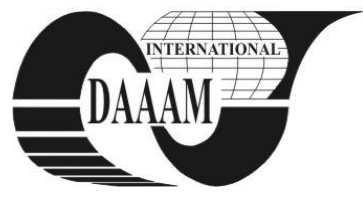

\title{
DIFFERENCES IN LEVEL OF EDUCATION OF INTERNET USERS IN EUROPEAN DEVELOPED AND EUROPEAN POST-COMMUNIST COUNTRIES
}

\author{
ZOROJA, J[ovana]
}

\begin{abstract}
This article investigates the level of education of Internet users in European developed countries and European post-communist countries. Using data from Eurostat the gap between European developed countries and European postcommunist countries in level of education of Internet users is measured. The main assumptions are that older and less educated inhabitants in European post-communist countries use Internet to the lesser extent compared to the European developed countries, but the difference dimishes with age group 16-24 and higer level of education. Considerably lower usage of Internet and a low level of education could be significant barriers towards further economic development of European post-communist countries.

Key words: internet usage, education, European developed countries, European post-communist countries, age, Eurostat
\end{abstract}

\section{INTRODUCTION}

The Internet, first used for communication, is now a tool in almost every aspect of business and everyday life (e.g. social interaction, education, payment). According to Internet World Stats there were 1.9 billion Internet users worldwide in 2010 (http://www.internetworldstats.com/stats.htm, Internet World Stats). However, differences in using Internet between countries are still significant (Wallsten, 2003).

European post-communist countries have achieved substantial progress in the recent years. However, many of these European post-communist countries are far behind the European developed countries. According to the Information Society Indicators Estonia and Slovakia are leading countries which made the biggest progress, but there are many more other countries that lag behind, like Hungary, Bulgaria and Romania (Zon, 2005).

Internet influences the economic growth and productivity of the country (Wallsten, 2003). Indjikian and Siegel (2005) confirmed that there is a strong positive correlation between Internet usage and economic growth. The fact that a number of countries lag behind in usage of Internet is particularly important since Internet offers broad range of possibilities for business (Indjikian and Siegel, 2005).

There are many factors that influence the use of Internet such as: socioeconomics and demographic variables, infrastructure, education (Colley and Maltby, 2008). Level of education and age are among the most important factors for Internet usage (van Deursen, A.J.A.M et al., 2011).

The goal of this research is to compare the level of education of Internet users in European developed countries and European post-communist countries. We want to explore whether there have been positive shifts in the period 2006-2010 in the percentage of inhabitants that use Internet and their level of education.

On the bases of these findings we define expectations related to the results of this research:

- Hypothesis 1: Older and less educated inhabitants in European post-communist countries use Internet to a lesser extent compared to European developed countries.
- Hypothesis 2: Younger and better educated inhabinants in European post-communist countries and in European developed countries use Internet to the same extent.

The paper is organized as follows. After the introduction, research methodology and sample characteristics are presented. In the third part empirical results and statistical data are presented. Final part of the paper discusess the results of the research and future research.

\section{RESEARCH METHODOLOGY AND SAMPLE CHARACTERISTICS}

Data from Eurostat collected as part of the i2010 initiative (A European Information Society for growth and employment, http://ec.europa.eu/information_society/eeurope/i2010/index_e n.htm) were used for this article during the research. Out of 34 countries, there were no data for Liechtenstein and Switzerland and Turkey was left out from the analysis, because it is neither a European developed country nor could be considered as European post-communist country. Other 32 European countries (Table 1) are divided into 2 groups: European developed countries and European post-communist countries.

Data were collected from the household surveys conducted by the Central Bureaus of Statistics (CBS), and the data relate to the first quarter of the reference year. The data for Internet usage and level of education were used in this analysis.

\begin{tabular}{|l|l|}
\hline \multicolumn{1}{|c|}{$\begin{array}{c}\text { European developed } \\
\text { countries }\end{array}$} & \multicolumn{1}{|c|}{$\begin{array}{c}\text { European post-communist } \\
\text { countries }\end{array}$} \\
\hline $\begin{array}{l}\text { EU 15 } \\
\text { Belgium, Denmark, } \\
\text { Germany, Ireland, } \\
\text { Greece, Spain, France, } \\
\text { Italy, Luxembourg, } \\
\begin{array}{l}\text { Netherlands, Austria, } \\
\text { Portugal, Finland, Sweden } \\
\text { and UK }\end{array}\end{array}$ & $\begin{array}{l}\text { EU members from 2004 } \\
\text { Czech Republic, Estonia, } \\
\text { Latvia, Lithuania, Hungary, } \\
\text { Poland, Slovenia, Slovakia }\end{array}$ \\
\hline $\begin{array}{l}\text { Others } \\
\text { Norway, Iceland, Cyprus } \\
\text { and Malta }\end{array}$ & Bulgaria and Romania \\
\hline
\end{tabular}

Tab. 1. European developed countries and Post-communist countries

Percentage of individuals in a particular country that used Internet at least once within the last 12 months and level of education was investigated. Groups of different levels of education (low-primary school, medium-high school and highuniversity) and age groups (16-24, 25-54 and 55-74) were compared between European developed and European postcommunist countries.

According to data provided by Eurostat mean and standard deviation at the country-group level were calculated. MannWhitney non-parametric test was used in order to test statistical significance of the observed countries. SAS Software V9.1.3 was used for all statistical analysis. 


\section{EMPIRICAL RESULTS}

Table 2 presents the percentage of individuals using the Internet according to age and education in the period from 2006 to 2010 .

Percentage of Internet users with low level of education and in all age groups has increased in both groups of countries from 2006 to 2010 (Table 2). In age group 16-24 there is almost no difference between European developed and European postcommunist countries. The highest difference is for the inhabitants in age group 25-54. The lowest percentage of inhabitants with low education who use Internet in European post-communist countries is among age group 55-74, and there was only $0,7 \%$ of seniors in European post-communist countries in 2006 who used Internet. Mann-Whitney test showed that the difference between the percentages of inhabitants with low level of education who use Internet in European developed and European post-communist countries is not statistically significant for age group 16-24 and is statistically significant for age groups 25-54 and 55-74 in both 2006 and 2010 year.

\begin{tabular}{|c|c|c|c|c|c|c|c|}
\hline \multirow[b]{2}{*}{ Year } & \multirow[b]{2}{*}{ Age } & \multicolumn{2}{|l|}{ Mean } & \multicolumn{2}{|c|}{ Standard deviation } & \multirow[b]{2}{*}{$\begin{array}{l}\text { Mann- } \\
\text { Whitney } \\
\text { U }\end{array}$} & \multirow{2}{*}{$\begin{array}{l}\text { Exact } \\
\text { Sig. } \\
{\left[22^{2 *}(1\right.} \\
\text { tailed } \\
\text { Sig.)] }\end{array}$} \\
\hline & & $\begin{array}{l}\text { European } \\
\text { developed } \\
\text { countries }\end{array}$ & $\begin{array}{l}\text { Post- } \\
\text { communist } \\
\text { countries }\end{array}$ & $\begin{array}{l}\text { European } \\
\text { developed } \\
\text { countries }\end{array}$ & $\begin{array}{l}\text { Post- } \\
\text { communist } \\
\text { countries }\end{array}$ & & \\
\hline & & \multicolumn{6}{|c|}{ Level of Education: LOW } \\
\hline 2006 & $16-24$ & $83,2 \%$ & $83,8 \%$ & $16,7 \%$ & $14,8 \%$ & 58,0 & 0,742 \\
\hline 2010 & $16-24$ & $93,1 \%$ & $87,9 \%$ & $6,8 \%$ & $14,4 \%$ & 80,0 & 0,347 \\
\hline 2006 & $25-54$ & $49,7 \%$ & $15,3 \%$ & $29,1 \%$ & $8,8 \%$ & $16,5^{* *}$ & 0,004 \\
\hline 2010 & $25-54$ & $64,1 \%$ & $36,5 \%$ & $24,8 \%$ & $19,9 \%$ & $41,0^{* *}$ & 0,004 \\
\hline 2006 & $55-74$ & $19,7 \%$ & $0,7 \%$ & $18,1 \%$ & $0,5 \%$ & $10,0^{* *}$ & 0,005 \\
\hline 2010 & $55-74$ & $28,8 \%$ & $5,8 \%$ & $19,3 \%$ & $4,8 \%$ & $26,5 * *$ & 0,000 \\
\hline & & \multicolumn{6}{|c|}{ Level of Education: MEDIUM } \\
\hline 2006 & $16-24$ & $89,9 \%$ & $80,7 \%$ & $11,0 \%$ & $13,6 \%$ & 36,0 & 0,064 \\
\hline 2010 & $16-24$ & $97,3 \%$ & $93,8 \%$ & $3,9 \%$ & $7,4 \%$ & 61,0 & 0,073 \\
\hline 2006 & $25-54$ & $75,4 \%$ & $44,9 \%$ & $19,3 \%$ & $18,9 \%$ & $22,5^{* *}$ & 0,000 \\
\hline 2010 & $25-54$ & $86,6 \%$ & $72,3 \%$ & $14,6 \%$ & $15,0 \%$ & $41,5^{* *}$ & 0,006 \\
\hline 2006 & $55-74$ & $44,1 \%$ & $11,8 \%$ & $20,6 \%$ & $7,3 \%$ & $11,0^{* *}$ & 0,000 \\
\hline 2010 & $55-74$ & $61,3 \%$ & $27,4 \%$ & $21,2 \%$ & $11,8 \%$ & $21,5^{* *}$ & 0,000 \\
\hline & & \multicolumn{6}{|c|}{ Level of Education: HIGH } \\
\hline 2006 & $16-24$ & $95,6 \%$ & $93,6 \%$ & $5,9 \%$ & $8,2 \%$ & 41,0 & 0,624 \\
\hline 2010 & $16-24$ & $97,8 \%$ & $98,8 \%$ & $3,7 \%$ & $2,0 \%$ & 79,0 & 0,786 \\
\hline 2006 & $25-54$ & $91,6 \%$ & $89,3 \%$ & $8,9 \%$ & $7,9 \%$ & 51,0 & 0,251 \\
\hline 2010 & $25-54$ & $96,6 \%$ & $96,2 \%$ & $4,8 \%$ & $2,1 \%$ & 65,5 & 0,107 \\
\hline 2006 & $55-74$ & $68,9 \%$ & $46,6 \%$ & $18,6 \%$ & $14,1 \%$ & $20,0^{* * *}$ & 0,008 \\
\hline 2010 & $55-74$ & $80,5 \%$ & $65,1 \%$ & $14,8 \%$ & $8,7 \%$ & $35,5^{* *}$ & 0,002 \\
\hline
\end{tabular}

Tab. 2. Percentage of individuals using the Internet according to age and education (** statistically significant at $1 \%$ level)

Percentage of Internet users with medium level of education in all age groups has increased in both groups of countries from 2006 to 2010. The lowest usage of Internet is among inhabitants in the age group 55-74 in European post-communist countries, and the highest usage is among age group 16-24 in European developed countries. However, age group 16-24 in European post-communist countris is not far behind. MannWhitney test showed that the difference between percentage of inhabitants with middle level of education that use Internet in European developed and European post-communist countries is not statistically significant for age group 16-24, and is statistically significant for the age groups $25-54$ and 55-74 in both 2006 and 2010 year.

The percentage of Internet users with high level of education and in all age groups has increased in both groups of countries from 2006 to 2010. In 2010 there are a higher percentage of young people who use Internet in Euroepan postcommunist than in European developed countries. In 2006 there is almost half of senior inhabitants who use Internet and during the period of five years that percentage increased to $65,1 \%$ in European post-communist countries. Mann-Whitney test showed that the difference between the percentage of inhabitants with high level of education that use Internet in European developed and European post-communist countries is not statistically significant for age groups 16-24 and 25-54, and is statistically significant for age group 55-74 in 2006 and 2010.

\section{DISCUSSION}

This article explores the level of education and age of Internet users in European developed countries and in European post-communist countries based on the data collected by the Eurostat. Inhabitants in European developed countries use Internet more intensively in almost all groups depending on age and level of education. Such findings support our first hypothesis. However, in 2010 the revers in favour of European post-communist countries occurs. In 2010 there is a slightly higher percentage of inhabitants in European post-communist countries with high level of eduation and in age group 16-24 who use Internet $(98,8 \%)$ compared to the same group in European developed countries $(97,8 \%)$. It might be concluded that developments of telecommunications, technology and economic growth in both groups of countries have led to an increase in the number of Internet users only in highly educated inhabitants, which supports our second hypothesis. Research made by Orviska and Hudson (2009) also confirmed that Internet access is higher for young people highly educated. Future studies are planned to broaden this research and to investigate the difference between sexes, if males or females use Internet more in different age groups in European developed countries or in European post-communist countries.

\section{REFERENCES}

Colley, A., Maltby, J. (2008). Impact of the Internet on our lives: Male and female personal perspective, Computers in Human Behavior, Vol. 24

Indjikian, R., Siegel, D. S. (2005). The Impact of Investment in IT on Economic Performance: Implications for Developing Countries, World Development, Vol. 33, No. 5.

Orviska, M., Hudson, J. (2009). Dividing or uniting Europe? Internet usage in the EU, Information Economics and Policy, Vol. 21

Van Deursen, A.J.A.M et al. (2011). Rethinking Internet Skills: The Contribution of gender, age, education, Internet Experience and hours online to medium- and contentrelated Internet skills, Poetics, doi: 10.1016/j.poetic.2011.02.001

Wallsten, S. (2003). Regulation and Internet Use in Developing Countries, Development Research Group, The World Bank.

Wetzl, A. (2010). Digital Education in Eastern Europe: Romanias Modern Affair with Technology, Computers and Composition, Vol. 27

Zon, H. (2005). The variety of information society development paths in central Europe, AI and society, Vol. 19, Issue 3.

***Internet World Stats, Available from: http://www.internetworldstats.com/stats.htm, Accessed $(2011 / 03 / 25)$

***i2010 - A European Information Society, Available from: http://ec.europa.eu/information_society/eeurope/i2010/inde x_en.htm, Accessed (2011/03/31) 